\title{
Tax policy for business entities under the conditions of association with the European Union: features and optimization directions
}

\author{
George Abuselidze*, and Inga Gogitidze \\ Batumi Shota Rustaveli State University, Georgia
}

\begin{abstract}
Under the conditions of EU association, one of the important for Georgia is to create such tax policy that shall be agreeable and settled with the economic systems of developed countries. The efficiency of the tax system depends on the optimal tax policy, according to which highly available and modern standard-oriented business environment is created. In 2017, the Parliament of Georgia passed the reform of profit tax that is aimed to free the business entities from profit tax during the reinvestment process. All the above mentioned maintains the topicality of ongoing reforms in Georgia. The goal of the research is to identify the impact of the new tax system on the Gross Domestic Product, the stream of investments, stimulation of business, and the period, after which the results of the reform will be favourable for the economic. There are various researches and scientific publications on the given issue. According to the study, the reform will produce a long-term macroeconomic effect that will mainly aim to favour small and middle scale businesses. Liberal tax approaches are advancing Georgia's investment attractiveness, reflecting an increase of investments. This work is based on Estonian experience presented in statistics and international studies. The information processed by experts and researchers helps us to evaluate the impact of this reform on Georgia.
\end{abstract}

\section{Introduction}

Nowadays, the economy as a whole body is composed of market mechanisms and state instruments complex approach to which demands highlighting fiscal policy one of the highly significant policies of the country's financial politics. According to Cleomar Gomes da Silva \& Flavio Villela Vieira [9], Fiscal policy has become an important economic tool in dealing with the consequences of the crisis. Tax policy ensures the efficient functioning of the state economic system. Any effective strategy or tactic of the state to stabilize the economy is a thoughtful policy reflected in sound tax law, a fair system of tax administration. It is essential to note that it is impossible to establish effective market relations without a well-functioning tax system. Theoretically and practically understood, scientifically justified taxes can have a positive influence on economic activity and production capacity. The effectiveness of the tax system is linked to optimal tax policy [4, 6, 10-12, $16,19,23,25-27]$, which creates the most optimal, affordable and up-to-date business environment. Besides, optimization shall mean solving of two important tasks, namely: maximum mobilization of budget revenues and taking into consideration paying capacity of tax payers in imposing of tax rates. Besides, it should be also taken into account that even in condition of full admissibility of tax burden, taxes may be seriously distorted. Topicality of research of income taxation problems is also conditioned with sharp manifestation of negative trends of effect of tax policy on the pace of economic activity [1].

The purpose of this paper is to discuss the theoretical and practical aspects of the Estonian state as an "Economic Miracle" and to represent Georgian perspectives of the Estonian model and its actual results. The following tasks are set to achieve the goal:

- Determining priorities and characteristics of the "Estonian" model;

- Evaluation of the effectiveness of the "Estonian" tax mechanisms in the economy of Estonia;

- Presentation of tax environment and tax stimulation mechanisms that exist in Georgia;

- Estimation of the "Estonian" model impact on the performance of business entities.

The purpose of this study is to determine the impact of tax policy on business activities and evaluate its development directions.

The methodological basis of the research. The methodological basis of the research is legal and economic aspects of tax policy. This paper uses works by the local and foreign authors, legislative base, statistical information and other research materials. The information displayed in the work is formed on the database of the National Statistics Office of Georgia, Ministry of Finance, Ministry of Economy and

* Corresponding author: george.abuselidze@bsu.edu.ge 
Sustainable Development of Georgia and other structures.

\section{Literature review}

The work uses publications from local and foreign authors, legal bases, articles, scientific research, statistical information and other research materials. Out of those, it is important to analyse the studies and opinions of experts on the Estonian model, such as: Masso, Merikull \& Vahter's [21] research shows that corporate tax reform in Estonian companies has increased the number of liquid assets and reduced debt financing. The study also confirms the positive effects on investment and labour productivity. According to the authors, such development of events have contributed to the sustainability of firms, making it easier for Estonian companies to handle the 2008 financial crisis. Bellak \& Leibrecht [7] studies show that it is improbable to correlate the increased investments in Estonia only to corporate income tax reform. Aforementioned may be due to the factors such as labour market, market size and other related issues etc.

According to the authors $[20,22,24]-$ a stable business environment, a low levels of bureaucracy and corruption, protection of private property, the rule of law, solid guarantees of investment protection and a consistent economic policy of the state have guaranteed Estonia's "economic miracle".

Within the project, financed by the USAID, economists [22, 24] have developed a general equilibrium model of neoclassical economic growth, according to which:

- Reform has a supportive effect on investment. The stock capital will grow by $3.23 \%$ in 1.5 years. The reform will lead to an increase in net investments;

- Total private consumption will rise by $0.85 \%$ in 1.5 years;

- The reform will increase the government's annual budget deficit by a maximum of $3 \%$. However, a $1 \%$ growth in income tax and a $1.25 \%$ VAT increase would eliminate the deficit.

The result of the reform will be visible in about 1.5 years.

\section{Influence of tax policy on activities of business entities and directions for optimization}

\subsection{Tax mechanisms for regulating the activities of business entities}

One of the main tools of state regulation of business activities is tax policy, which in turn is a system of planned actions of the state based on economic, legal and controlling activities in taxation.

The world experience shows (for example, the Baltic States, Turkey) that economic development is always linked to structural changes in the economy. It is a process that involves the distribution of economic activities between agriculture, services and industry, followed by the modernization of the economy, the increase in employment and labour productivity. The private sector is the main navigator of structural changes in the economy.

At the modern stage of development, Georgia aims to blend into the world economic climate, and it can be achieved by harmonizing the business environment. The tax policy represents an important part of economic integration, which in turn impacts the production sector, competition, production and sale. In combination with the mentioned, taxes affect the social and political situation in the country.

In the framework of the Association Agreement between Georgia and the European Union, fiscal legislation has been brought closer to EU legislation in our country. Tax administration was simplified and tax sanctions were optimized. The limitation period defined by the Tax Code has been gradually reduced in the country. Most importantly, the legal relationship between the state and business was based on the principles of equality.

According to the international indexes, Georgia is already in the leading position: as reported by the World Bank's Doing Business 2019 release, Georgia ranks 6th out of 190 countries in terms of ease of doing business [13]. In this view, Georgia stands out in the European and Central Asian region as a state that has taken important steps towards efficient administration.

Georgia holds the leading position in terms of low tax burden following Qatar, the United Arab Emirates and Hong Kong (Fig. 1) [5].

At present, according to the tax legislation of Georgia 6 taxes are in place instead of 21 (Table 1).

Table 1. Current tax rates in Georgia

\begin{tabular}{|c|c|}
\hline Tax & Rate \\
\hline Profit & $15 \%$ \\
\hline Income & $20 \%$ \\
\hline VAT & $18 \%$ \\
\hline Import & $0 \%, 5 \%, 12 \%$ \\
\hline Property & $<1 \%$ \\
\hline Dividend & $5 \%$ \\
\hline
\end{tabular}

Source: Ministry of Finance of Georgia [29]

Specific tax regimes (Table 2) are in place, for:

- Individuals with microbusiness status;

- Entrepreneur Individuals with small business status;

- Individuals with fixed taxpayer status.

Individuals with a particular status enjoy certain benefits under the Georgian legislation that allow them to develop their business activity. Specific features and advantages of the specific taxation are as follows.

In Georgia, there are certain types of tax privileges to stimulate business development and draw additional foreign investments to a particular geographic area. In 2015 , to stimulate the development of mountain regions, a law on the development of such regions was developed. The initiative is aimed at individuals and 
legal entities operating in settlements with a highmountain status.

Advantages:

1. An entrepreneur with a high mountain status is free from the income tax for 10 years after receiving the status.

2. An entrepreneur with a high mountain status is free from the profit tax for 10 years after receiving the status. 3. Property owned by a highland-status enterprise is exempt from the property tax for 10 years.

Business, registered in the free industrial zone, is:

1. Exempt from all taxes except income tax (remuneration of hired workers).

2. Foreign goods introduced into the zone are exempt from the value-added tax.

3. In case of conducting certain activities, it is freed from the obligation to obtain a license/permit or uses a simplified procedure for obtaining them.

4. In the case of supplying (import) the products produced within the zone into other territories of Georgia, the import tax shall be cleared.

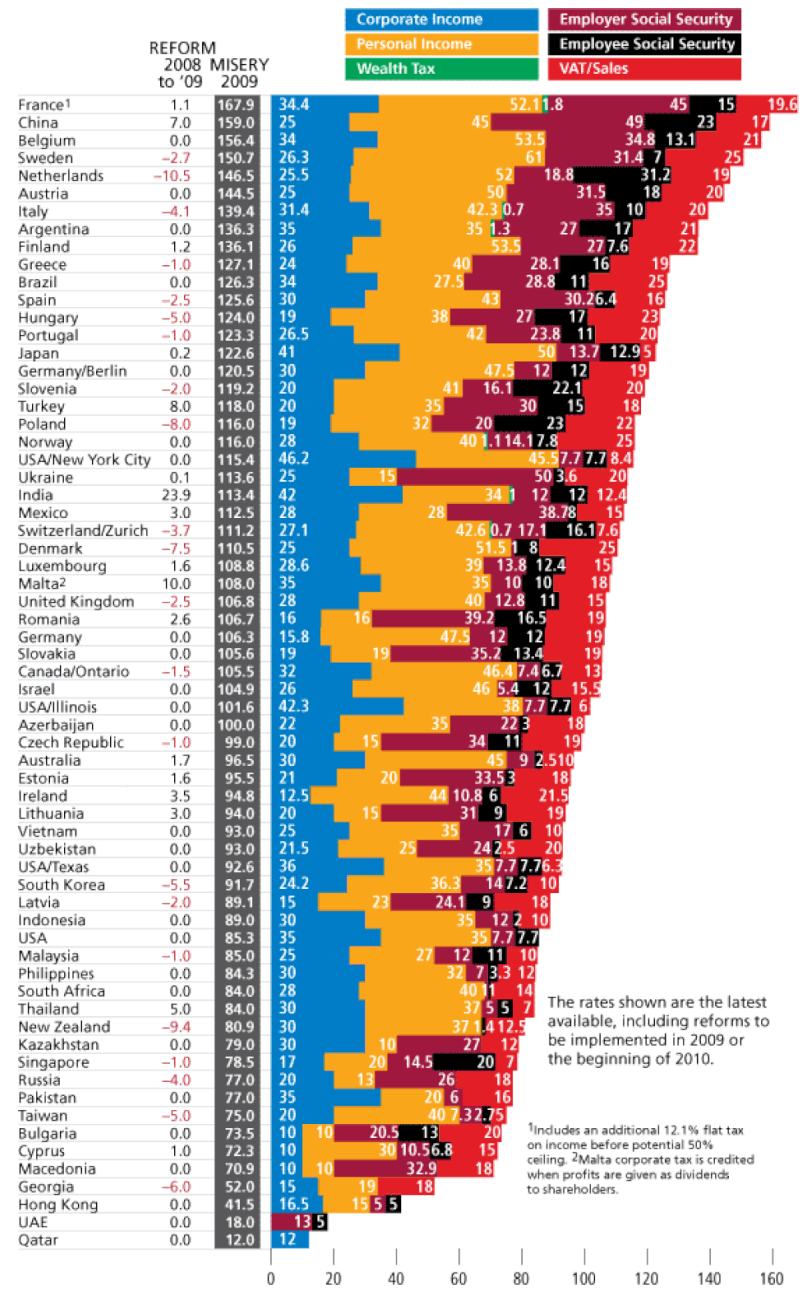

Fig. 1. Tax Misery and Reform Index.

Despite implemented reforms, the rating of the countries according to Global Competitiveness index (GCI) is as follows: Switzerland $(5,81)$; Estonia $(4,78)$; Lithuania (4,60); Azerbaijan (4,55); Russia (4,51); Latvia $(4,45)$; Turkey $(4,39)$; Georgia $(4,32)$; Armenia
$(4,07)$; Ukraine $(4,00)[2]$. As we see, Georgia cannot be proud of the absolute deficit of free competition, while the constant concern of companies in developed countries is exactly the competition. The catalyst for generating a competitive environment is the development of business entities that encourage the distribution of modern standards and lifestyles. This, in turn, limits the growth of large city agglomeration and forms a solid foundation for the advancement of socialeconomic development.

Table 2. Specific tax regimes: conditions and advantages.

\begin{tabular}{|c|c|c|}
\hline & Conditions & Advantages \\
\hline $\begin{array}{l}\text { Micro business - The } \\
\text { status applies to } \\
\text { individuals who } \\
\text { independently } \\
\text { conduct economic } \\
\text { activity: }\end{array}$ & $\begin{array}{l}\text { Their total gross } \\
\text { income does not } \\
\text { exceed } 30,000 \mathrm{GEL} \\
\text { during the calendar } \\
\text { year; } \\
\text { They do not have } \\
\text { employees; } \\
\text { Their commodity } \\
\text { supply (materials, } \\
\text { finished products, } \\
\text { unfinished } \\
\text { production) does } \\
\text { not exceed } 45,000 \\
\text { GEL; } \\
\text { They are not VAT } \\
\text { payers }\end{array}$ & $\begin{array}{l}\text { Individuals with } \\
\text { Micro business } \\
\text { status are exempt } \\
\text { from the income } \\
\text { tax; } \\
\text { Individuals with a } \\
\text { Micro business } \\
\text { status are exempt } \\
\text { from the use of a } \\
\text { cash register. }\end{array}$ \\
\hline $\begin{array}{l}\text { Small business- } \\
\text { The status is granted } \\
\text { to entrepreneurs } \\
\text { who: }\end{array}$ & $\begin{array}{l}\text { Their total gross } \\
\text { income does not } \\
\text { exceed 500,000 } \\
\text { GEL during the } \\
\text { calendar year; } \\
\text { Their commodity } \\
\text { supply does not } \\
\text { exceed } 150,000 \\
\text { GEL. }\end{array}$ & $\begin{array}{l}\text { Chargeable } \\
\text { income of an } \\
\text { individual with a } \\
\text { small business } \\
\text { status is taxed at } \\
1 \% \text {; } \\
\text { The income of an } \\
\text { individual with } \\
\text { the above status is } \\
\text { taxed at } 3 \% \text { only } \\
\text { if the entrepreneur } \\
\text { has the } \\
\text { opportunity to } \\
\text { provide } \\
\text { documents for } \\
60 \% \text { of the } \\
\text { expenses (other } \\
\text { than salary); } \\
\text { The opportunity } \\
\text { of simplified tax } \\
\text { accounting. }\end{array}$ \\
\hline
\end{tabular}

Source: composed by the author based on tax code data

USAID research indicates that changes are not always clear and easy to understand. This can be the basis for unintentional offence and fines. In conclusion, it can be stated that despite the internationally recognized liberal tax policy, companies' view towards the country's tax legislation is more negative than positive. This is due to frequent changes to the Tax Code and vague records, as well as a high tax pressure.

In this situation, minor changes in certain segments of the economy, including in the tax system, the 
fragmented transformation of parts of the economy do not lead to the desired outcomes [2]. According to the economic theory of supply with the view of resolving the problem of country's economy tax decrease is necessary. With low tax rates business owners have opportunity to accumulate, which provides complete utilization of business potential and increase of GDP of the country [3].

\subsection{Taxation measures for business entities in Estonia and its efficiency}

One of the traits of the Estonian model is the simplicity of tax administration and tax legislation, which simplifies certain types of business procedures. Tax administration is implemented by a risk management program, rigidly controlling tax avoidance cases. The simplicity of the tax declaration directly impacts the number of tax penalties and fines, which also significantly lessens the cost of tax administration for both the state and the business.

A stable business environment, little bureaucracy, low levels of corruption, protection of private property, the rule of law, trustworthy guarantees of investment security and a consistent economic policy of the state have ensured Estonia's "Economic Miracle" [8, 17, 22, 24].

The business climate in Estonia is distinguished by a free trade system. Estonia has a high credit rating in the region. There are four free trade zones in the country. Estonia is ranked 7th out of 180 countries in the 2018 Index of Economic Freedom by the Wall Street Journal and the Heritage Foundation (table 3).

Table 3. Index of economic freedom of the world -2018 .

\begin{tabular}{|c|c|}
\hline I & Hong Kong \\
\hline II & Singapore \\
\hline III & New Zealand \\
\hline IV & Switzerland \\
\hline V & Australia \\
\hline VI & Ireland \\
\hline VII & Estonia \\
\hline VIII & Great Britain \\
\hline IX & Canada \\
\hline $\mathbf{X}$ & United Arabian Emirates \\
\hline
\end{tabular}

Source: Index of economic freedom, 2018 [8, 15]

By the 2018 year data, Estonia has broken the record for world startups (Fig. 2). The progress of startups in Estonia is driven by many factors. The most important ones are tax environment, simple registration of companies, IT sector state programs and stable economic environment.

It is important to note that Estonia designates substantial funds from the budget. According to 2018 statistics, Estonia has invested 328 million Euros in startups, which is the highest financial figure compared to other years.

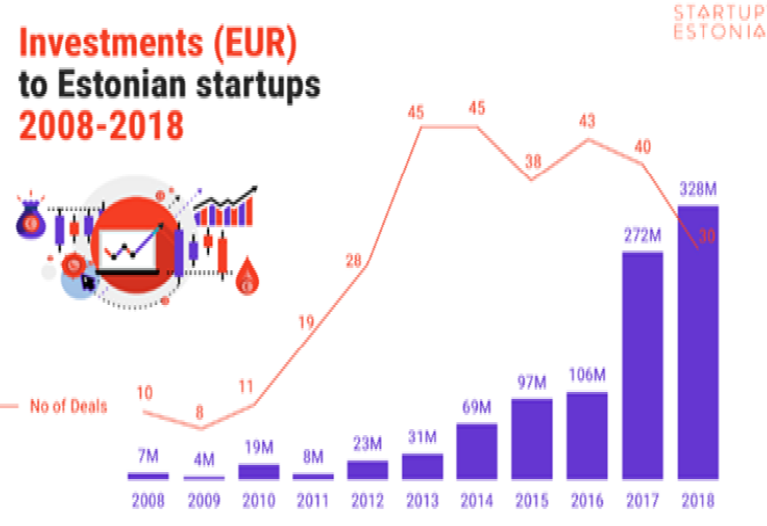

Fig. 2. Startup investments in Estonia (EUR) - 2018 Source: startupestonia [28]

It is also remarkable that the increase in the number of employees in startups is reflected in the taxes paid by employees. As of 2018, this figure is 46 million euros, in 2017 - 36 million euros and 2016 - 27 million euros. These numbers show that annual growth between each year equals to $30 \%$.

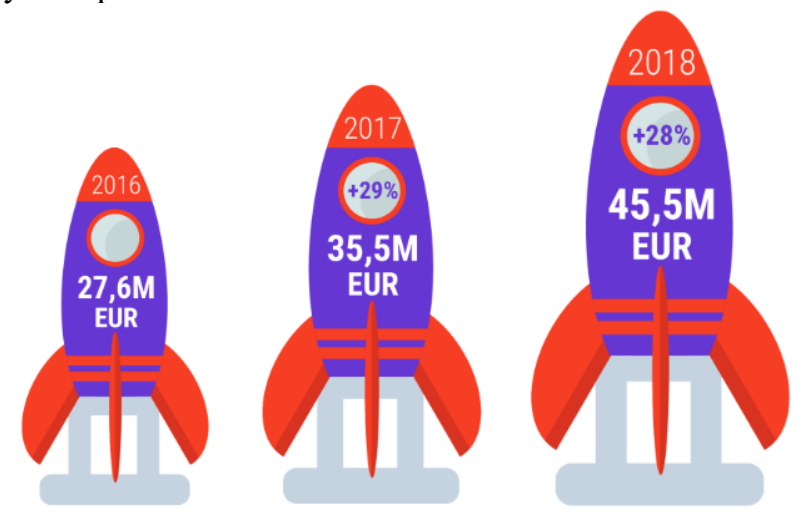

Fig. 3. Employee paid taxes for Estonian startups - 2018 Source: startupestonia [28]

\subsection{Comparison of business environment of Estonia and Georgia and tax mechanism harmonization matters}

The so-called "Estonian" model of profit tax has been operating in the Georgian tax system since January 1, 2017 , intending to promote economic growth based on business reinvestment opportunities. The peculiarity of the Estonian model is that the company's profit tax is suspended until the profit is distributed, enabling the business entity to conserve a certain amount of financial resources and to utilise these funds for reinvestment. The Estonian model is mainly focused on the rational allocation of financial results.

The Estonian model in Georgia provides:

1. Business opportunity progress;

2. Creating an attractive business atmosphere;

3. Promotion of capital growth;

4. Increase the company's liquidity;

5. Accelerate economic growth.

However, any change in the level of reinvestment may result in a reduction in tax revenue. Increasing tax 
revenues in this field can be achieved through improved tax administration or increased tax rates. Foretelling the effects of tax administration is difficult, unlike rate rises, which allow us to more or less analyze them. In the case of Georgia, raising rates is prohibited by the Economic Freedom Act. However, by the same act "the Government of Georgia has the right to request a temporary increase of taxes for a period not exceeding three years. In this case, the referendum is not held (Organic Law of Georgia on Economic Freedom).

In general, if we compare the investment part of Estonia and Georgia according to the so-called Benchmark Georgia, the investment business environment is as follows:

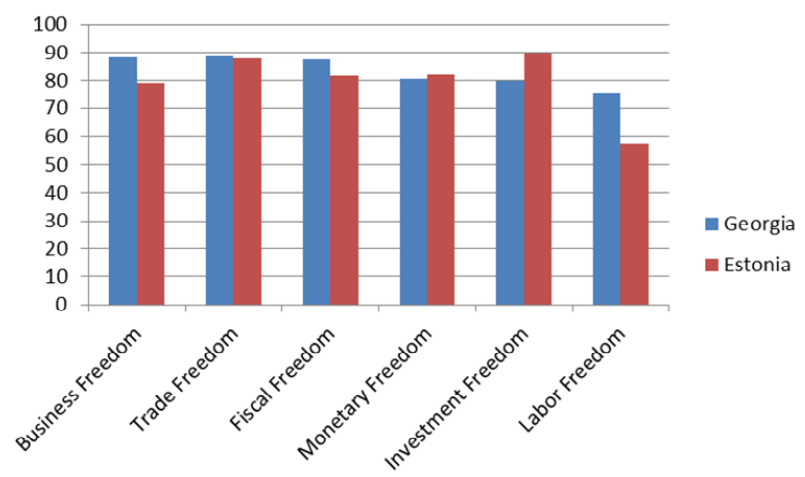

Fig. 4. Investment environment, Georgia/Estonia Source: Compiled by the authors based on data from the Invest in Georgia [18]

As we can see from figure 4, according to the Freedom of Doing Business, Georgia scores 9.5 points more than Estonia. Georgia is also in the leading position with the indexes of trade, fiscal, legal freedom.

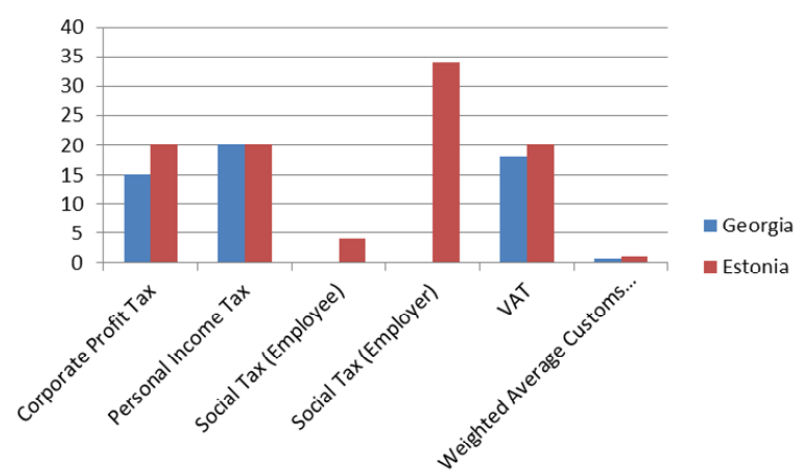

Fig. 5. Taxes \%, Georgia / Estonia

Source: Compiled by the authors based on data from the Invest in Georgia [18]

According to figure 5, related to the taxes, corporate profit tax, social tax and VAT in Estonia are higher than in Georgia.

According to the Tax Code of Georgia, the object of taxation with the Estonian model of income tax is:

- Distributed earnings (including price differences);

- Non-economic expenses and payments;

- Complimentary supply (e.g supply of goods, services and funds);
- Representative expenditure above the limit.

By the "Estonian" model, a taxpayer is a resident enterprise as defined by the Tax Code, as well as a nonresident one operating in Georgia with a permanent enterprise and/or receiving income from a Georgian source.

The profit tax rate is $15 \%$. Profit tax-deductible amount is obtained by dividing the number of payouts/expenses divided by 0.85 .

By the "Estonian" model, the profit tax calculation period is one calendar month. The profit tax monthly declaration is submitted to the taxation organ by the taxpayer (electronic form), no later than the 15th day of the following month of the reporting month and in the same period, a profit tax shall be paid.

According to the Estonian model, taxpayers are all the enterprises, except:

- Financial institutions;

- Systemic-electronic form of the slots;

- Companies defined by law on "Oil and Gas";

- A non-resident enterprise whose income from a source in Georgia does not belong to its permanent establishment in the country;

- An individual entrepreneur;

- Individuals with microbusiness status;

- Individuals with fixed taxpayer status;

- Organisations (including: LEPL, N(N)LE, charity organisations).

The Estonian model eliminates double taxation. Under the model, an enterprise has the right to account for the amounts of tax accumulated and paid on the distribution of net profits received in given years (20082016), provided that profits are distributed over that period.

To avoid double taxation, on June 7, 2017, within the framework of the OECD Week, Georgia signed Multilateral Convention to Implement Tax Treaty Related Measures to Prevent Base Erosion and Profit Shifting (MLI).

The main purpose of the treaty "Avoidance of Double Taxation and the Prevention of Fiscal Evasion" is to promote deeper economic cooperation and attract investments. The texts of the agreements concluded by Georgia are based on the Organization for Economic Cooperation and Development (OECD) model and set out the principles of taxation between countries.

In particular, income collected from activities carried on by legal entities and individual entrepreneurs in the other country shall be taxable in the country in which it was obtained or in the residence state. In the case of taxation in the income source country, the resident country undertakes the responsibility, to avoid double taxation, to consider the tax paid in the source state. The main objective of the agreement is also to avoid tax evasion, which is achieved by the introduction of international standards for the exchange of information for tax purposes.

Nowadays, the treaty "Avoidance of Double Taxation and the Prevention of Fiscal Evasion" is in force in 55 countries [29].

In a situation where access to cheap financial resources for small and medium-sized enterprises in 
Georgia is complicated, the untaxed undistributed profit, which results in more resources available for reinvestment, are of particular importance. "Research and development", which requires additional expenses from companies, is exactly what most businesses in Georgia need, and the Estonian model encourages exactly that kind of reinvestment. It is almost impossible for Georgian businesses to establish a place on the EU market without additional financial expenses. The undistributed profit of potential exporters in the EU market may play a significant role in raising that export potential.

"The results of a study by Alexander Lungvist (New York University) and Mikhail Smoliansky (Federal Reserve System) support the assumption that profit tax cuts can have notable positive economic outcomes only when such fiscal policies are implemented in times of economic recession. Researchers also suggest that large scale profit tax cuts are needed to accomplish real socialeconomic benefits" [14].

It should also be remarked that Estonia's "economic miracle" was not linked to only one specific tax reform, but also to complex changes that ultimately drove to effective results and economic growth. Concerning Georgia, no complex policy has been fulfilled, and therefore, sharing one particular reform in a country where the tax culture is distinct from Estonia, in our opinion will not produce any long-term positive results.

The tax policy implemented by the state needs to support economic growth and development, that is why on the one hand, it is important for the country to properly and rationally-design tax system and the actions that will not harm output and investments, on the other hand, the government should carry out their functions and the tasks required for the implementation of activities and programs using funds accumulated through taxes. Furthermore, the tax policy should be structured so that the increase in budget revenues does not suppress the activities of private entrepreneurship. It should ensure the fairness of economic conditions and the development of nominal operating conditions of the economy. Optimal tax policy might well lead to the growth and improvement of the economy to a balanced budget and not to an artificially balanced budget.

\section{Conclusions and recommendations}

Corporate profit tax reform in Estonia, that is introducing Estonian model for profit tax at the legislative level is connected to the complex state reforms, in which we include legislative changes, currency reforms, the effective tax administration, the creation of a private sector-friendly environment, and other reforms which created the evenly profitable business climate. If we assess the situation in Georgia, we will see that no such steps have been taken in our country. Sharing the so-called Estonian model alone will not have the economic effect it had in Estonia, as Estonia's tax policy was highly incorporating, unlike Georgia's.
In addition to all this, the tax legislation in Georgia is undergoing constant changes, which creates an unstable atmosphere for business entities. In Estonia, the efficiency of corporate income tax reform was helped by a steady macroeconomic environment, which is not a stable process for Georgia. The effective functioning of the tax system is influenced by a tax culture, which is low in Georgia, unlike Estonia, where business entities are aware that they must participate in the formation of budget revenues. The results of the reform are more effective in Estonia than in Georgia, as the reduction of tax pressure in Estonia before 2000 allowed companies to reinvest profits. As for Georgia, the tax policy was already liberal before the profit tax reform, unlike Estonia.

The stimulus programs in Estonia are diverse, in particular, the Start-up Estonian program, where the budget allocates substantial funds. As for Georgia, the Startup - Georgia program is also progressing, which is a strengthening factor for new businesses. Beforementioned programs play an important role in the evolution of business activities.

Finally, to compensate for the loss of budget funds owing to profit tax reform, the state should focus on effective tax administration measures, targeted use of budget revenues and budget expenditure reductions.

\section{References}

1. G. Abuselidze, Optimality of Tax Policy on the Basis of Comparative Analysis of Income Taxation. European Journal of Sustainable Development 9, 272-293 (2020). doi:10.14207/ejsd.2020.v9n1p272

2. G. Abuselidze, Fiscal Policy Directions Of Small Enterprises and Anti-Crisis Measures on Modern Stage: During the Transformation of Georgia to the EU. Science and Studies of Accounting and Finance: Problems and Perspectives 12, 1-11 (2018). doi:10.15544/ssaf.2018.01

3. G. Abuselidze, The prospects of budget revenue in the aspect of optimal tax burden, in Whither Our Economies Conference November 2011. Business System Economics and Management, ed. by D. Daujotait, E. Freitakas, P. Nemeček, vol. 2 (Mykolas Romeris University, 2011), p. 161

4. S.A. Allayarov, Combination of fiscal and stimulating functions of the tax system to ensure financial and economic security. American Journal of Economics and Business Management 3, 64-69 (2020). doi:10.31150/ajebm.Vol3.Iss 1.116

5. J. Andersen, Tax Misery and Reform Index. (Forbes, 2009), https://www.forbes.com/global/2009/0413/034-taxmisery-reform-index.html\#2c109d8343b3. Accessed 13 Jan 2020

6. M.Zh. Arzayeva, D.A. Sadykhanova, Effect of the tax burden on the activities of business entities. The Journal of Economic Research \& Business Administration 120(2), 130 (2017) 
7. C. Bellak, M. Leibrecht, Do low corporate income tax rates attract FDI? - Evidence from Central- and East European countries. Applied Economics 41, 2691-2703 (2009). doi:10.1080/00036840701320217

8. S. Cnossen, Tax policy in the European Union: a review of issues and options. FinanzArchiv/Public Finance Analysis 58(4), 466-558 (2001)

9. C.G. Da Silva, F.V. Vieira, Monetary and Fiscal Policy in the World Economy: Coordination Before and After the Financial Crisis (2014), https://editorialexpress.com/cgibin/conference/download.cgi?db_name $=$ SBE36\&pa per_id=18. Accessed 13 Jan 2020

10. N. Davidenko, H. Skrypnyk, Z. Titenko, O.V. Zhovnirenko, Modeling of the optimum level of financial provision of Ukrainian enterprises' innovative activities. Global Journal of Environmental Science and Management 5, 197205 (2019). doi:10.22034/GJESM.2019.05.SI.22

11. D. Dharmapala, J. Slemrod, J.D. Wilson, Tax policy and the missing middle: Optimal tax remittance with firm-level administrative costs. Journal of Public Economics 95(9-10), 1036-1047 (2011). doi:10.1016/j.jpubeco.2010.10.013

12. P. Diamond, S. Emmanuel, The case for a progressive tax: From basic research to policy recommendations. Journal of Economic Perspectives 25, 165-190 (2011). doi: $10.1257 /$ jep. 25.4 .165

13. Doing Business (International Bank for Reconstruction and Development / The World Bank, $16^{\text {th }} \quad$ Edition, 2019), https://www.doingbusiness.org/content/dam/doingB usiness/media/Annual-Reports/English/DB2019report_web-version.pdf. Accessed 13 Jan 2020

14. M. Edjibia, Estonia is a country with an example of success (Europe for Georgia, 2017), http://eugeorgia.info/ka/articleblog/48/estonetiqueyana. Accessed 13 Jan 2020

15. Drinking on the street and the 2018 index of economic freedom (Brandon Donnelly, 2018), https://brandondonnelly.com/2018/02/21/drinkingon-the-street-and-the-2018-index-of/. Accessed 13 Jan 2020

16. M. Golosov, M. Troshkin, A. Tsyvinski, Optimal taxation: merging micro and macro approaches. Journal of Money, Credit and Banking 43, 147-174 (2011). doi:10.1111/j.1538-4616.2011.00413.x

17. A. Hazak, Companies' Financial Decisions Under the Distributed Profit Taxation Regime of Estonia. Emerging Markets Finance and Trade 45(4), 4-12 (2009). doi:10.2753/REE1540-496X450401

18. Invest in Georgia (Enterprise Georgia, 2018), https://www.investingeorgia.org. Accessed 13 Jan 2020

19. B. Jacobs, A.L. Bovenberg, Human capital and optimal positive taxation of capital income. Int Tax
Public Finance 17, 451-478 (2010). doi:10.1007/s10797-009-9120-5

20. O. Kiuila, A. Markandya, Can transition economies implement a carbon tax and hope for a double dividend? The case of Estonia. Applied Economics Letters 16, 705-709 (2009). doi:10.1080/13504850701221816

21. J. Masso, J. Meriküll, P. Vahter, Gross Profit Taxation Versus Distributed Profit Taxation and Firm Performance: Effects of Estonia's Corporate Income Tax Reform (Working Papers of Eesti Pank, 2011), https://www.eestipank.ee/publikatsioon/toimetised/2 011/22011-jaan-masso-jaanika-merikull-priitvahter-gross-profit-taxation-versus-distributedprofit. Accessed 13 Jan 2020

22. J. Masso, K. Krillo, Labour markets in the Baltic States during the crisis 2008-2009: the effect on different labour market groups. The University of Tartu Faculty of Economics and Business Administration Working Paper 79 (2011). doi:10.2139/ssrn. 1734378

23. G.N. Mankiw, M. Weinzierl, D. Yagan, Optimal taxation in theory and practice. Journal of Economic Perspectives 23, 147-174 (2009). doi:10.1257/jep.23.4.147

24. J. Meriküll, Labour market mobility during a recession: the case of Estonia (Working papers of Eesti Pank. No. 1/2011, 2011), https:/www.eestipank.ee/en/publication/workingpapers/2011/12011-jaanika-merikull-labour-marketmobility-during-recession-case-estonia. Accessed 13 Jan 2020

25. E. Saez, S. Stantcheva, Generalized social marginal welfare weights for optimal tax theory. American Economic Review 106, 24-45 (2016). doi:10.1257/aer.20141362

26. P.B. Sørensen, The theory of optimal taxation: what is the policy relevance?. Int Tax Public Finance 14, 383-406 (2007). doi:10.1007/s10797-007-9024-1

27. S. Stantcheva, Optimal taxation and human capital policies over the life cycle. Journal of Political Economy 125, 1931-1990 (2017). doi:10.1086/694291

28. 2018: Records for the Estonian startup sector, new wave of entrepreneurs in the community (Startup Estonia, 2018), https://www.startupestonia.ee/blog/2018-recordsfor-the-estonian-startup-sector-new-wave-ofentrepreneurs-in-the-community. Accessed 13 Jan 2020

29. Tax Code of Georgia (Ministry of Finance of Georgia, 2017), http://taxinfo.ge/images/stories/sxva/tax_code_of_g eorgia.pdf. Accessed 13 Jan 2020 